Article

\title{
Sustainable Development of Operations: Actors' Involvement in the Process of Energy Efficiency Improvements
}

\author{
Naghmeh Taghavi
}

check for updates

Citation: Taghavi, N. Sustainable Development of Operations: Actors' Involvement in the Process of Energy Efficiency Improvements.

Sustainability 2021, 13, 6121.

https://doi.org/10.3390/su13116121

Academic Editor: Jurgita

Antuchevičienè

Received: 20 April 2021

Accepted: 27 May 2021

Published: 28 May 2021

Publisher's Note: MDPI stays neutral with regard to jurisdictional claims in published maps and institutional affiliations.

Copyright: (C) 2021 by the author. Licensee MDPI, Basel, Switzerland. This article is an open access article distributed under the terms and conditions of the Creative Commons Attribution (CC BY) license (https:/ / creativecommons.org/licenses/by/ $4.0 /)$.
Division of Service Management \& Logistics, Chalmers University of Technology, 41296 Gothenburg, Sweden; naghmeh.taghavi@chalmers.se

\begin{abstract}
This study empirically investigates the involvement of actors in the process of energyefficiency improvements in operations to align strategic sustainability goals across and within operations. The study analyzes development efforts stemming from actors' decisions and actions that contribute to the process of energy efficiency improvements using semi-structured interviews and secondary information. Data is analyzed using thematic coding. The study deepens the understanding of how firms undertake the transition towards integrating strategic goals for energy efficiency into operations by strategizing for energy efficiency improvements through actors' involvement. By exploring actors at both strategic and operational levels, and their decisions and actions, the study includes examples of different approaches, namely, top-down vs. bottom-up and inside-out vs. outside-in, thereby conceptualizing the process of energy-efficiency improvements in terms of a framework that outlines the entities of this process. The study further provides an integrative framework for the development efforts by different actors and presents propositions for incorporating energy-efficiency improvements in daily strategic and operational decisions and actions instead of regarding it as a separate or an add-on process.
\end{abstract}

Keywords: sustainable development of operations; energy-efficiency improvement; operations strategy; actors' involvement

\section{Introduction}

Given the large volumes of energy consumed for operational processes to produce products and services, the efficient use of energy is a major sustainability strategy [1] and an important enabler for achieving sustainable operations in the manufacturing and processing sector [2]. Operations rely on energy sources such as fossil fuels or renewable energy in terms of end use [3] related to both production processes and support processes such as heating and lighting [4]. Energy management has been found to be a determining factor in managers' environmental concerns [5]. Moreover, energy-efficiency improvement has gained attention in operations management (OM) literature as a means of increasing environmental sustainability, particularly in relation to reducing resource consumption in operational processes [6]. Similarly, the literature on energy management has identified OM as an area with "large" and "unexploited" potential for improving energy efficiency [7]. Energy-efficiency improvements can be achieved by means of technological changes, better organizational management, or behavioral changes [8]. However, practices herein vary and new approaches for energy-efficiency improvements in operations still need to be better understood by practitioners [9]. Although several studies have addressed the matter of improving energy efficiency in operations companies [10], the subject is dominated by the technical perspective [7]. Moreover, although the need for strategic support has already been addressed as a driver for energy-efficiency improvements in operations [11], the literature is dominated by an operational focus on technological measures related to production processes [12]; as such, the existing literature lacks a strategic management perspective and organizational integration [13]. 
Previous literature has suggested that there are positive effects of cross-functional actors' involvement, including executive managers and workers, in the alignment of strategic goals across the organization at different hierarchical levels and within different functions, including the operations function [14-16]. More specifically, the positive effect of worker involvement in the alignment of operational improvements and environmental improvements in day-to-day activities was proposed by Lonogoni et al. in 2015 [15]. The important role of climate-friendly top management practices on energy efficiency has been researched [17]. Motivation from managers and workers has been highlighted as an important enabler for energy-efficiency improvements [18]. Moreover, operations managers' involvement has been found to significantly increase the adoption of energy-efficiency initiatives due to their knowledge of production processes [19]. Economic [20] and behavioral barriers [21] within the organization towards the adoption of cost-effective actions for energy-efficiency improvements have been addressed. An empirical study analyzed the involvement of internal and external actors in the decisionmaking process for industrial energy-efficiency technologies [22]. Accordingly, it is argued that understanding actors' involvement aids to align strategic sustainable development goals, including energy-efficiency improvements, across and within the operations function through shared understanding [23] and alignment of achievements [16]. However, despite recognizing the importance of actors' involvement, the literature needs to contextualize and explain the involvement of actors from different organizational levels in the process of energy-efficiency improvements.

By analyzing different actors' involvement through the process of energy-efficiency improvements to reveal doings and sayings of people who perform energy-efficiency improvements as a practice, this study offers empirical evidence that although sustainability is considered an isolated, add-on performance objective for the operations function, energyefficiency improvements are integrated as a practice into daily operational improvements, as actors at the operational function work continuously on improving their socio-technical systems and processes [24]. Meanwhile, focusing on understanding energy-efficiency improvements as an emerging improvement process allows an emphasis on the development aspect of sustainable development as a "process of change" rather than a "fixed state of harmony" [25] (p. 43).

Against this background, the purpose of this study is to empirically investigate the involvement of different actors in the process of improving energy efficiency by focusing on the actors' development efforts, whereby actors are in the foreground as individuals who influence the improvement process and enable the alignment of strategic sustainability goals regarding energy efficiency across and within operations; the study thus answers the following research question: How are different actors involved in and shape the process of energy-efficiency improvements?

The remainder of this paper is organized as follows. Section 2 reviews the literature and conceptual approaches towards improving energy efficiency through actors' involvement in the context of operations strategy (OS). Section 3 describes the study method in detail. To answer the research question, a description of the practices (what) and the actors (who) based on the empirical findings is presented in Section 4. Section 5 analyzes the findings to address the research question and the analytical aspect (how), and discusses the findings with reference to the literature. The final section draws conclusions.

\section{Theoretical Background and Conceptual Framework}

The theoretical underpinning of this paper is the literature on OM that concerns environmental sustainability and literature on energy-efficiency management that relates to OM. The goal of the conceptualization is to delineate energy-efficiency improvements in terms of a framework that outlines the entities of the process and integrates the development efforts by different actors in an integrative framework. 


\subsection{The Process of Energy-Efficiency Improvements: Integration of Energy Management in Sustainable Operations Management}

The field of sustainable operations management, rooted in the mainstream literature of both $\mathrm{OM}$ and sustainable development, is concerned with the efficient use of resources (environmental) and less costly (economic) processes that maintain standards for workers' well-being (social) at the operational level [26]. Traditionally, performance objectives, such as cost, flexibility, lead time, reliability, and quality [27], have been linked to operational resources through a sequence of structural and infrastructural decisions within the operational function through an OS [28]. Previous literature has included sustainability as an additional performance objective in OS [29]. The literature, however, also indicates that sustainability is a complex and unfamiliar paradigm for operations managers [30]. The operations function interprets competitive priorities and focuses on aspects consistent with its functional goals and productivity. Relatively, actors at the operations function do not typically think in terms of sustainability and do not view their operations through the lens of sustainability $[23,31]$.

Improving energy efficiency is a key aspect of sustainable development in operations [2] as well as an integral environmental sustainability practice. It emphasizes aligning operational decisions and practices with corporate goals for sustainable development related to energy and as an isolated additional performance objective cascading from the firm's sustainability strategy. Relatively, practices towards improving energy efficiency affect sustainability performance in operations. Moreover, energy efficiency, corresponding to the paradigm of pollution-prevention strategies, embedded within sustainable development, and relating to reducing resource consumption in operational processes [6], has been described as a possible path to improve eco-efficiency [32,33]; it also provides an opportunity to focus on a unit of resource consumption and cost of processes that consume large amounts of energy [34].

It must also be noted that operational decisions and practices set the operational conditions for energy utilization through such settings as lead time and flexibility. In addition, energy-efficiency improvements can also have a positive effect on other performance objectives through non-energy benefits such as more reliable production or reduced maintenance cost [35]. Hence, although traditional performance objectives directly affect operational performance, and energy-efficiency improvements directly affect sustainability performance, performance objectives can be viewed as determinants of energy utilization through operational decisions and practices, and energy-efficiency improvements can be viewed as enablers of operations performance objectives. Thus, a focus on energy efficiency improvements allows companies to develop environmental sustainability and other operations' performance objectives simultaneously through tangible decisions and practices in operations [9].

The literature on energy management acknowledges the inclusion of strategy/planning, implementation/operations, control, organization, and culture [7]; it also emphasizes the need to bridge the strategic and operational levels [36], and strategic and operational integration [37]. Although actions to reduce energy use in core operations' processes such as production or support processes such as lighting and heating [4] belong to the operational dimension of energy management [7], with a dominant focus on cost-efficiency, there are also actions and decisions mainly related to authorization and resource allocation, such as investment decisions for energy-efficiency measures, which are strategic in nature [37]. Therefore, in addition to an operational focus, management-related factors also need be acknowledged for the integration of energy management in operations [38]. A lack of such organizational integration of energy efficiency can result in energy-efficiency improvements not being considered a part of core business, which can then create obstacles for energy-efficiency investments [13]. Similarly, the vital role of organizational drivers and structure on energy-efficiency improvements has been proposed [39].

In this research, energy-efficiency improvements are defined as "an increase in energy efficiency as a result of technological, behavioral, and/or economic changes" [40]. 
Summarizing a review of the extant literature on process frameworks for sustainability and energy management, and including both strategic and operational levels in the organization [36], the process of energy-efficiency improvements is conceptualized as an emerging improvement process following a sequence of activities in five steps. The process starts with goal-setting, in which the top management formally expresses its intention and commitment linked to energy performance through an energy policy/strategy that includes targets for energy efficiency [8,41]. These targets can be set in terms of energy performance indicators at the aggregated company level, tactical plant level, or process/appliance level, which relates to work units and is used to monitor efficiency and control the processes [42]. This step is followed by identification, which looks at generating projects based on ideas and opportunities. In order to identify and analyze the potential to enhance energyefficiency improvements, the energy-related status quo is often determined through an energy audit [7]. The next step, financing, allocates resources for the implementation of the assessed and approved action plans. Different methods used to evaluate energy-efficiency investments have been reviewed by Chiaroni et al. [22]. Based on the developed action plan, different actions are implemented at the operational level in the implementation step. Finally, elements of performance evaluation are controlled through the measuring, reporting, and benchmarking step to evaluate whether the operations have resulted in greater energy efficiency, and to benchmark and report the results.

\subsection{Actors' Involvement in the Process of Energy-Efficiency Improvements: Top-Down vs. Bottom-Up, Inside-Out vs. Outside-In}

Research on the development of sustainability in operations has emphasized the importance of an organizational model focused on achieving sustainability goals and strategic alignment [43]. Previous research has called for "the process of strategy implementation by utilizing resources and influencing individual and/or collective action towards energyrelated objectives" [7] (p. 3705). Energy-efficiency improvements in operations, similar to other operational performances, are an outcome of a process through which the company deploys their strategic goals for energy efficiency into objectives and practices that the operations function can perform. Such a deployment process consists of the formulation and implementation of an OS for energy-efficiency improvements, and involves different actors, who may be within or outside of the company [22], and internal or external to the operations function. Moreover, it requires strategic and operational decisions to be taken at the individual level or at the level of an internal (e.g., management team, board of directors) and/or external (e.g., multiple stakeholders) team of individuals with different backgrounds, interests, and value frames [44]. Following the OS process research perspective, this study investigates actors' involvement by analyzing which actions individuals perform, who performs those actions, and how the actions are performed [45]. Accordingly, energy-efficiency improvements, integrated into actors' decisions, are aligned with strategic goals for energy efficiency vertically across different organizational levels, and horizontally across different functions.

Vertical involvement distinguishes between the top-down and bottom-up approaches. In line with the OS research stream, vertical involvement considers actors' positions at either the top management level or in the operations function. Generally speaking, following the dominant top-down perspective in OS process research [46], the top management establishes overall goals and preferred dimensions of competitive priorities for the company and is responsible for allocating resources. Following a hierarchical process model, measurable performance objectives and actions plans in terms of improvement programs are then articulated by operations managers. Action plans are assessed to secure and allocate resources. Thereafter, lower-level employees of the operations function carry out actions required to achieve the goals. Indicators of the top-down approach in the literature include: 
1. Leadership and building a reputation, which lead to a change in organizations' priorities and structures [43,47];

2. Companies' long-term vision to set policies supplemented by specific tactical principles [47,48]; and

3. Appointment of sustainability-related roles or champions in the organization $[47,49]$.

However, previous research on OS has explicitly expressed the need to broaden the traditional process view to provide alternative perspectives [50] and explore the process at different organizational levels [51]. In addition, previous research has suggested that there are positive effects of cross-functional actors' involvement in different hierarchical levels and functions on strategic alignment $[14,16]$. Therefore, it is necessary to understand how the involvement of different actors influences the process of improving energy efficiency to align operations with strategic sustainability goals and improve energy efficiency through day-to-day decisions and practices in operations. Indicators of bottom-up decisions and actions include the following:

1. Sustainability is regarded as a part of the day-to-day operations and work [48];

2. Bi-directional communication [52]; and

3. Incentives to follow sustainability and create motivation $[48,52]$.

In order to emphasize organizational learning for continuous improvement through employee involvement and feedback layers, this study also investigates, using the bottomup perspective in OS process research [46], bottom-up action plans that emerge from operations function employees' participation in day-to day operations.

In addition to vertical involvement, the study also distinguishes horizontal involvement between the inside-out and outside-in approaches, in line with the research on strategic management and management control for sustainability focused on supporting decision-making for sustainability issues [53-55]. The inside-out approach, following the resource-based view [56], relies on an internal resource base to exploit opportunities and/or neutralize threats. The inside-out approach is driven by business strategies and objectives derived from business strategies with a focus on the successful implementation of the sustainability objectives and with sustainability performance reported as a last step in the process. This approach condenses goals into key performance indicators and information to support decision-making. Previous research identified examples of an inside-out approach in the treasure-hunt teams used by Toyota and Energy Kaizens [57], or sustainability balanced scorecards. The focus of the inside-out approach is on achieving superior performance by developing, possessing, capitalizing on, and deploying resources that are valuable, scarce, inimitable, and non-substitutable [56]. In contrast, similar to the market-based view, the outside-in approach relies on actors in the external environment, such as stakeholders, energy service suppliers, and engineering consultants, to evaluate a company's energy usage and exploit opportunities. These outside actors are "perceived as sources of expertise" and "have access to company decision makers" [58] (p. 3).

In sum, four different approaches of actors' involvement in the process of energyefficiency improvement are investigated in this research: top-down vs. bottom-up and inside-out-vs. outside-in. These approaches differ in terms of the origin of the decision or action through the improvement process as well as the sequence of steps.

\section{Methods}

To better understand the field of sustainable OM, there is a need to develop and test theories comprehensively [59]. This study adopted an exploratory approach and sought to better understand the process of energy-efficiency improvement with the use of evidence. The method adopted should have enabled an understanding of complex phenomena, the holistic characteristics of real-life events (i.e., vertical and horizontal involvement of actors), and an in-depth description of different decisions and practices from the actors' viewpoints. Thus, the study employed qualitative data collection in the form of semi-structured interviews [60] to compile rich empirical evidence. However, although qualitative data allowed greater proximity than surveys, the emerging nature of the process 
of energy-efficiency improvements required diversity of research subjects. Hence, data collection through semi-structured interviews was implemented in 19 companies; the large number of companies enabled us to find answers for the descriptive framing of the process of energy-efficiency improvements (what and who), whereas the closeness to the actors provided through the semi-structured interviews made it possible to answer the analytical aspect (how) of the research question. Given that the focus of the study was on the process of energy-efficiency improvements in operations, the unit of analysis was defined as the development effort for improving energy efficiency.

\subsection{Sampling}

Company selection followed purposive sampling, as defined by Bryman and Bell [61] with high level of experience as a selection criterion [60], in order to ensure a profound knowledge of the development efforts for improving energy efficiency. Therefore, the sample comprised companies in various markets that work with energy-efficiency improvements in a systematic way and with a proven record of working with energy-efficiency improvements. The final sample included 19 companies from both energy-intensive and non-energy-intensive industries, as suggested by Rhodin and Thollander [62]; this enabled an in-depth understanding across a broad spectrum based on different contexts, as recommended by Abdul-Rashid et al. [34]. To make sure that the companies held such a selection criterion, all the chosen companies in the sample belonged to one of the following categories: (1) companies benefitting from tax exemptions by working on energy-efficiency management and continuously improving energy efficiency as a result of legislation obligation, or (2) companies voluntarily working with energy efficiency and having achieved energy-efficiency improvements as a result of working on previously implemented operational improvements such as lean. Table 1 provides an overview of the sample and interviewees' profiles.

Table 1. Individual interviewee characteristics.

\begin{tabular}{|c|c|c|c|}
\hline Case & Industry & Respondent & Additional Evidence \\
\hline 1 & Chemical, metal powder & Energy Coordinator & Semi-structured interview/website \\
\hline 2 & Chemical, polyethylene & Energy Manager & Semi-structured interview \\
\hline 3 & Paper & Production Leader & Semi-structured interview/internal documents \\
\hline 4 & Paper & Development Engineer & Semi-structured interview/internal documents \\
\hline 5 & Paper & $\begin{array}{l}\text { Energy Technique Manager and } \\
\text { Project Leader }\end{array}$ & Semi-structured interview/internal documents \\
\hline 6 & Chemical & Strategic Energy Manager & Semi-structured interview \\
\hline 7 & Pulp and paper & Plant Manager & Semi-structured interview \\
\hline 8 & Agricultural & $\begin{array}{l}\text { Automation Engineer working with } \\
\text { process support }\end{array}$ & Semi-structured interview/website \\
\hline 9 & Automotive & Production Technical Manager & Semi-structured interview \\
\hline 10 & Automotive & $\begin{array}{l}\text { Energy Technique and Development } \\
\text { Engineer }\end{array}$ & Semi-structured interview/media \\
\hline 11 & Pulp & Energy Controller & Semi-structured interview/internal documents \\
\hline 12 & Packaging & Managing Director & Semi-structured interview \\
\hline 13 & Aluminum & Quality and Environment Manager & Semi-structured interview/website \\
\hline 14 & Water treatment products & Plant Energy Coordinator & Semi-structured interview \\
\hline 15 & Automotive & Energy Coordinator at plant level & Semi-structured interview/survey \\
\hline 16 & Automotive & Energy Manager & Semi-structured interview \\
\hline 17 & Pulp & Operator & Semi-structured interview/internal documents \\
\hline 18 & Home appliance & $\begin{array}{l}\text { Global Energy Strategy Director for } \\
\text { Operations }\end{array}$ & Semi-structured interview/website/media \\
\hline 19 & Aluminum & $\begin{array}{l}\text { Production and Process Development } \\
\text { Manager }\end{array}$ & Semi-structured interview \\
\hline
\end{tabular}




\subsection{Data Collection}

In-depth semi-structured interviews were used as the primary source of data collection. The researcher used a general interview guide but also allowed concepts to emerge from the participants' end. The initial interview guide was structured around the process of energy-efficiency improvements explained in Section 2.1. This structure was used to set common points and boundaries around the development efforts for improving energy efficiency to help the researcher understand what takes place within each step and who performs which action. The interview guide was validated by presenting it in a workshop to practitioners in multinational companies. All interviews were pre-arranged, with each respondent being informed about the study to ensure relevance and confirm support. The respondents were from various organizational levels but were key players in improving energy efficiency. As such, this study demonstrates how those responsible for development efforts for improving energy efficiency think about the process so that the study could advocate for both strategic and operational levels of the organization (Table 1). Each interview lasted between 60 and $120 \mathrm{~min}$. Data collection was complemented by gathering additional information from select companies in the form of company documents, internal presentations, and internal and external sustainability and annual reports. Secondary evidence, such as publicly available data in the media or on company websites, was also used to corroborate and triangulate the answers from the interviewees.

\subsection{Data Coding and Analysis}

All responses were recorded and subsequently transcribed with the permission of the participants. Field notes, other internal company documents provided by the respondents, and transcripts were used in the analysis in which the data were worked from the ground up, as proposed by Yin [63]. Analysis was initiated by performing a within-case analysis of individual observations in the data and based on the priori codes, formed from the five predefined steps in the process; this enabled a broad understanding of how each company worked to improve energy efficiency. These individual analyses were then expanded with elements within and beyond the steps. This occurred by iteratively looking for common themes and patterns based on evidence through axial coding [64]. The codes were inductively developed not only from the questions, but also through the coding process. The relevant literature was reviewed, and the data were categorized, coded, and assessed based on actors' involvement vertically and horizontally in order to align strategic goals across and within operations. Table 2 illustrates the thematic structure for the process of energy-efficiency improvements and provides examples of how they are presented in the empirical data.

\subsection{Research Quality}

Due to the nature of this study, as well as its qualitative approach, four criteria were employed to evaluate the robustness of the results: credibility, transferability, dependability, and confirmability. To assure consistency of research results over time, i.e., dependability, a study protocol and an interview guide were developed based on the literature, which was used through the process of data collection. This common protocol and interview guide, as well as the recording and transcribing of data, was used to document all the steps of data collection to ensure stability and consistency. A database and complete chain of evidence were created during data collection as well as iteration between data and theory during the coding process. The findings were constantly verified by both academics and practitioners through presentations, discussions, and seminars to ensure credibility. Transferability of the findings to similar contexts was enabled through the rich data collected and detailed descriptions using power quotes. Discussion of collected data in relation to the literature was also used to ensure analytical generalization. Furthermore, the development of a conceptual framework and propositions enables the transferability of findings to other contexts by providing general categories and enables other scholars use the framework to 
elaborate on other practices of sustainability. Multiple sources of evidence were used in the research to reduce the risk of bias and assure the confirmability of the results.

Table 2. Thematic structure for actors' involvement approaches in the process of energy-efficiency improvements.

\begin{tabular}{|c|c|c|}
\hline $\begin{array}{l}\text { Thematic } \\
\text { Structure }\end{array}$ & Description & Example of How the Thematic Structure Is Operationalized in the Data \\
\hline \multicolumn{3}{|c|}{ Vertical Involvement } \\
\hline $\begin{array}{l}\text { Bottom-up } \\
\text { approach }\end{array}$ & $\begin{array}{l}\text { The process relies on } \\
\text { top management and } \\
\text { its intentions }\end{array}$ & $\begin{array}{l}\text { Corporate owners or board of directors set long-term goal with little or no } \\
\text { discussion at the plant level. } \\
\text { Corporate owners or board of directors develop some sort of policy or principle } \\
\text { that requires working with energy efficiency. } \\
\text { There are no proper short-term goals and employees just linearly break down the } \\
\text { long-term goal. } \\
\text { Energy fund exists at the corporate level, for which different plants have to submit } \\
\text { yearly applications for possible improvements. } \\
\text { For proposals with energy-efficiency improvements, a longer payback time } \\
\text { is accepted. } \\
\text { All proposals are evaluated based on a calculated life-cycle cost analysis together } \\
\text { with simple payback calculations. } \\
\text { Corporate owners or board of directors challenge the plant managers and } \\
\text { co-workers to set their own short-term goals. } \\
\text { Energy-responsible team or person at the plant level has the task of breaking } \\
\text { down the corporate goal. } \\
\text { All employees are involved in setting goals with shared responsibility as } \\
\text { improvement activities. } \\
\text { The company has different plants with different potentials for improvement, } \\
\text { which calls for goal-setting adequate to each plant. } \\
\text { Internal identified potentials through energy mapping are used to set goals. }\end{array}$ \\
\hline
\end{tabular}

Horizontal

Involvement

Inside-out approach

Outside-in approach
The process relies on internal resources
Improvement proposals come from all employees, especially those who are close to processes.

The energy management system is used as a tool to develop processes considering energy efficiency.

Incidents registered in a risk and opportunities database are used to identify improvement potentials.

The identification is done internally and continuously by stabilizing the processes. Energy mapping is done internally together with process owners and other key responsible people in the field.

Visualization is used for different organizational parts to indicate energy use and identify opportunities.

Previous outcomes of measurements are used to identify the potentials.

An incentive in the form of a monthly contest has been developed to motivate employees to come up with new ideas for improvement.

Benchmarking and best practices between different plants are used by plant representatives to identify potential.

A company-wide energy-services team of experts from all the plants is used to identify wastes and improvement potentials.

Potential is identified through a performance comparison with equivalent companies.

Industrial programs are used to bring recommendations.

Incentive agreements are used to identify potential.

The energy group identifies the potential using input from external sources, such as suppliers and contractors and even consultants.

External partners are used for the evaluation and measurement of the figures resulting from the analysis of operations by operators.

Certified energy experts (internal or external) are used to perform energy mapping. Some external actors such as property managers are involved in bringing in proposals. 


\section{Results}

This section presents the empirical data from the interviews and the secondary evidence. The presentation of the results revolves around the actors' development efforts in the five steps in the process of improving energy efficiency in which actors are involved; as elaborated in Section 2.2, these steps are goal setting; identification; financing; implementation; and measuring, reporting, and benchmarking.

\subsection{Setting Goals for Improving Energy Efficiency}

Three approaches for goal-setting were identified. The first approach is the unilateral, one-directional, top-down approach. Six interviewees mentioned a unilateral, one-directional, top-down approach in which long-term goals for energy efficiency are set by the top management with little or no discussion or engagement with the operational function employees. As a result, there are usually no tactical short-term goals for improving energy efficiency.

The second approach is the hybrid, connected top-down and bottom-up approach. This approach entails a mix of a predefined top-down approach and an emerging bottomup approach. As described by 10 interviewees, the long-term vision for improving energy efficiency in this approach is set by the top management and complemented by short-term tactical goals for the operations function connected to the identified improvement potential and action plans. Typically, the latter goals are created by a team or person responsible for energy at the plant level by involving employees with technical knowledge of operational processes. The goals set by the top management act mainly as initiators and supporters of the long-term vision of the organization. The visions from the top and the goals from the bottom are not necessarily formulated in the same way, but they point in the same direction. The reasoning for this approach is that operational function employees should be able to relate to the goals in their work tasks. As an energy-technique engineer in a paper company mentioned:

"The goals should be understandable for those who can influence them, i.e., the operators. It does not matter if the energy manager works all the time since the operators are the ones running the factory; they are there most of the hours and they must know that energy is important."

Even in automated processes where there is not much that operators can influence, they can actively influence the stop time, which, for example, accounted for $13 \%$ of the chemical company's energy costs in 2013.

For example, in one packaging company, which has a hybrid, connected top-down and bottom-up approach, the tactical goals for improving energy efficiency are set by co-workers in their own "improvement zones" in the factory. These goals are collected and communicated to the top management, which turns them into a realistic vision. As the managing director in this packaging company explained:

"The organization is turned upside-down. Operators are on the top ... Even if you work as an operator or in administration, every day you work towards improvement."

At a polyethylene company, an ambitious target was set when a new manager started and proposed the goal based on his experience. Subsequently, the operational managers were asked to set their own annual goals based on the proposed target and define the action plans, which would help them achieve their goals. At a metal powder company, the board of directors asks and challenges the plant management to set its own tactical goals on a yearly basis. According to the interviewee from this company, the corporate owners do not have the technical competence to identify the possibilities and potential at the plant level.

The third approach is the disconnected top-down and bottom-up approach. This approach is a mixture of a top-down and bottom-up approach, but with much more disconnect between the levels than in the second approach. As described by four interviewees, the work of the employees at the plant level for improving energy efficiency is not connected 
to the vision set out at the corporate level. The following reasons were identified for this disconnection: (1) The goals set by the top management are stated in simple terms and it is believed that their achievement does not need much effort, (2) operational employees do not consider that the goals set by the top management are achievable, (3) the top management does not understand the conditions at the production level, (4) there is a lack of communication between the corporate level and other levels (the interviewee was not aware of the corporate-level vision), (5) the formulation of corporate-level goals does not engage employees at the operational level, and (6) operators cannot understand how to achieve the goals set by the corporate level.

None of the interviewees identified a unilateral bottom-up approach or external actors as being involved during the goal-setting phase. However, two interviewees mentioned legislation as a motivation for implementing energy-efficiency improvements, not in terms of complying with existing regulations, but as being ahead of upcoming regulations to avoid any surprises. Two companies were forced to start working towards improving energy efficiency due to an outside crisis and only one company voluntarily worked to improve energy efficiency. Therefore, although external actors do not directly get involved in setting strategic goals for energy efficiency, they can affect the goals set.

\subsection{Identification of Opportunities for Improving Energy Efficiency}

According to the interviewees, the most frequently used measures to identify potential for improving energy efficiency are energy audits and energy mapping, which involve the monitoring and analysis of the operations to enable decision-makers to identify opportunities for improvement. As the energy-technique manager and project leader at the paper company mentioned:

"We expect a lot from our energy mapping, where we go through the whole factory and carefully obtain a picture of how we use energy. This way, we can see what is really possible."

However, the companies rely on both internal and external actors to identify potential for improving energy efficiency, which warrants that the companies maintain a fruitful dialogue between internal and external actors, as also revealed in the study findings. The involvement of internal actors of the operational function in identifying potential for improving energy efficiency can be observed in companies with high levels of in-house expertise and experience. According to the interviewees from these companies, their own employees are aware of existing improvement potentials, since they are familiar with the companies' own processes. By implementing this approach, companies want to combine operational and technical expertise with procedural and behavioral changes in their facilities.

External actors, such as suppliers, customers, property managers, other companies in the industrial sector, and contractors, are used as input for gauging the improvement potential, whereas external consultants are mainly used to perform energy audits. The energy audits propose action plans for improvement. However, these proposals are mainly on technical measures and do not typically propose radical procedural and behavioral changes. According to the energy coordinator in the chemical company, it takes too much time to explain to external consultants how the special technologies and processes work. Moreover, consultants rarely have a systematic overview and tend to ignore the risks of sub-optimization in their proposals.

\subsection{Financing Action Plans for Improving Energy Efficiency}

The results indicate that the capital investment decision-making for financing action plans for improving energy efficiency is a strategic matter driven by the top management. However, the approach of the firm towards how to finance the energy-efficiency improvements can enable the involvement of different actors, which can occur through the following approaches. 
Parity competition for capital is used by the top management to decide on all improvement proposals, including action plans for improving energy efficiency top-down, most commonly in the form of a simple payback. Some interviewees highlighted that for proposals of action plans to improve energy efficiency, a longer payback time was acceptable. Two interviewees mentioned that they use life-cycle cost analysis and traditional paybacks to avoid underinvestment in proposals with positive expected cash flows.

The capital set aside is dedicated funding for energy-efficiency improvement proposals at the corporate level. Although the capital set aside for action plans that aim at improving energy efficiency enables bottom-up involvement, the challenging issue is transferring the knowledge of the existence of these funds and the requirements to achieve them vertically throughout the organization. For example, in two companies in the pulp industry, the interviewees were aware of an energy fund at the corporate level; however, they believed that access to the fund was restricted and had never used it.

The interviews also revealed that companies' capital budgeting could follow a third approach through outside-in involvement. Three interviewees mentioned they had used some external funding through incentive agreements to finance action plans for improving energy efficiency. The energy supplier of an aluminum company supported all investments as well as the required competencies to implement such action plans. In return, the supplier was supposed to obtain a profit from these investments. The interviewee believed that this was a win-win agreement, since the company was able to build the missing competences and later finance and implement the action plans to improve energy efficiency internally. One of the companies in the automotive industry uses internal incentive agreements between departments. The savings from the incentive agreements were used to invest in new action plans for improving energy efficiency. One company obtained funding from the Swedish Energy Agency to conduct energy mapping and implement the identified action plans.

The interviews also revealed that many action plans for improving energy efficiency efforts do not always require separate capital budgeting. At the automotive company, improving energy efficiency occurs through eliminating waste, according to the interviewee. The company reduced its baseline electricity usage by around 30\% in 2015 without any new investments. The managing director in a packaging company, for example, highlighted that the company rarely invests in proposals that target only energy-efficiency improvement. However, action plans for improving energy efficiency are integrated into investments that aim to reduce losses in operations (e.g., eliminating waste, rework, and overproduction). To identify these losses in a better way, financial staff are placed in production to learn the processes. Two interviewees emphasized that all investment proposals in their company undergo an assessment for their potential to improve energy efficiency, which is one of the decision criteria for allocating funding.

\subsection{Implementation of Action Plans for Improving Energy Efficiency}

The interviewees revealed that the operational function does not differentiate between action plans for improving energy efficiency and other improvement proposals. If the proposal has a long-time horizon, needs large investments, and is approved by the organization, it is treated as a formal improvement project for which a temporary project organization is formed using skilled people from different organizational levels. The temporary project organization typically has a project leader and a steering group, and the size of the team can vary depending on how big the project is. In some companies, if the required skills and competence do not exist inside the company, consultants may be brought in. However, all interviewees believed that most action plans for improving energy efficiency were not that big and could be integrated into day-to-day operational improvements without a formal improvement project. 


\subsection{Measuring, Benchmarking, and Reporting Energy-Efficiency Improvements}

The analysis of the interviews indicates that companies that use energy-accounting approaches, such as internal energy management systems or standardized ISO 50001, use these approaches to gather data to follow up on the improvement efforts. The measures are mainly completed at the plant level. Interviewees considered that difficulties in using the measurements at the product level mainly are due to the variety of products with different energy usages. In one company, job dashboard measurement was introduced and a key performance indicator on electricity was used as one of the daily measures discussed in daily meetings. Another example involves one of the companies in the paper industry that measures energy usage continually and has implemented a real-time system that measures how much energy is used in production at any time and for each machine. The interviewee believed that this could increase operators' influence on improving energy efficiency.

Although some of the interviewees mentioned that they compared their energy measurement data with corporate goals, they struggled with benchmarking energy efficiency improvements at the organizational and industry levels. Even multi-plant companies mentioned that they had tried to benchmark against other plants, but it was very difficult to do so. One reason was that the measures are usually set as watts hour per volume, and differences in the produced volume make benchmarking difficult.

Benchmarking at the industry level was not used by the interviewed companies mainly due to competitiveness, as mentioned by the energy manager in a polyethylene company: "We are trying to find inspiration, but this is a competitive factor at the same time." Thus, progress in improving energy efficiency is mainly reported as a key performance indicator (KPI) in the annual corporate sustainability report.

\section{Discussion}

The purpose of this study is to empirically investigate the involvement of different actors in the process of improving energy efficiency by focusing on the actors' development efforts, whereby actors are in the foreground as individuals who influence the improvement process and enable alignment of strategic sustainability goals regarding energy efficiency across and within operations. The analysis of the results, summarized in Figure 1, exhibits the four approaches of different actors' involvement in the process of improving energy efficiency, in which vertical involvement distinguishes between the top-down and bottomup approaches and considers actors' positions at either the top management level or in the operations function, and horizontal involvement distinguishes between the insideout and outside-in approaches and relies on either internal resources or actors in the external environment such as stakeholders, energy-service suppliers, and engineering consultants. According to Figure 1, the process of energy-efficiency improvements is a double-loop layered approach that takes advantage of the different kinds of knowledge and competences from different actors. For example, whereas individual operational function employees have technical knowledge, middle-level production managers have an overview of the system. Moreover, whereas external actors, i.e., consultants, customers, suppliers, and professionals, have in-depth knowledge of alternative processes and methods, the internal operations actors who are "close to processes" have significant knowledge about the company's current processes and operations. By combining these approaches into an integrative approach, not only can the process benefit from linking the individual parts, but it can also emphasize organizational learning for continuous improvement through feedback layers. Based on the analyses of empirical data, the following propositions are offered for the alignment of strategic goals for energy efficiency across and within operations through the existing vertical and horizontal involvements. 


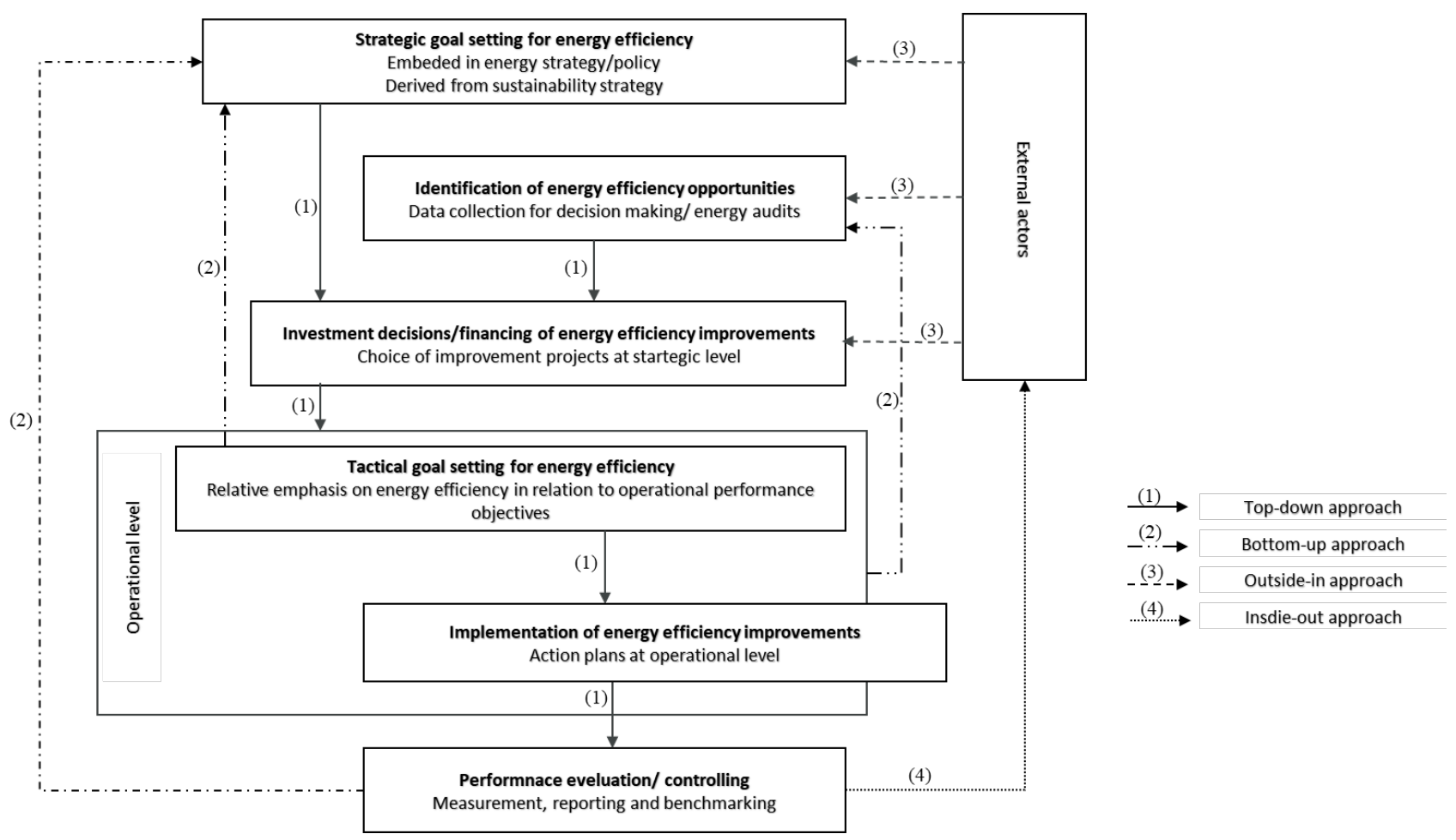

Figure 1. Conceptual integrated framework for the process of energy-efficiency improvements in operations.

Although motivation for improving energy efficiency makes goal-setting relevant, the analysis of the empirical data shows that the underlying reasons for prioritization of the development efforts for energy-efficiency improvement originate from different motivations.

The top-down approach of actors' involvement in the process of energy-efficiency improvement is embedded in cost and reflected through long-term (3-10 years) strategic goals set either by the company owners or the board of directors. Consequently, due to low and stable energy costs, as well as energy being regarded as a small cost portion of the total production cost in non-energy-intensive companies, energy-efficiency improvements in operations are not a high strategic priority. Therefore, since energy-efficiency improvements in operations require investments that might not pay off for decades, the short-term financial perspective is seen as a major hindrance for improving energy efficiency in operations. Prior research has discussed a high level of risk and low returns as major barriers to energy-efficiency investment decision-making [65]. Similar findings regarding proactive investments in environmental technologies have been presented in supply chains [66]. Although previous research, mainly in the field of green supply-chain management, argues that supply-chain partners, stakeholders, society, regulators, and particularly customers, pressurize organizations to adopt sustainable management practices $[59,67,68]$, this pressure was not recognized by the interviewed respondents. This confirms the findings by Alblas et al., who stated that "in reality, such sustainability pressures and incentives can be absent, or at best fuzzy, in some contexts... most of the companies experienced external incentives and information as either lacking or fuzzy" [69] (p. 533). Although stakeholder, regulation, and customer pressure have positive effects on eco-design strategy [67], they are not motivators for improving energy efficiency in operations. Based on the interviews, cost-cutting is the biggest managerial motivation for strategic goal-setting to improve energy efficiency. Although some companies view improving energy efficiency as not only an economic issue, it is still not associated with market requirements and is not considered a competitive advantage.

The data also revealed internal motivations, personal interest, and passion for working to improve energy efficiency as reasons for the emergence of bottom-up involvement. For example, the energy-technique manager in the paper company provided formal education 
in the field of energy and was very interested in his job, leading to an emerging bottom-up approach in the organization. Three interviewees mentioned that many young employees in the company have a personal interest in environmental issues, including in improving energy efficiency. One of the interviewees in the paper company was also interested in improving energy efficiency to make the work as easy as possible for the operators. According to this operator, flawed routines, inefficient equipment, waste, and rework are examples of what can affect operators in their daily work. These personal motivations, which initiate a bottom-up approach, are embedded in non-energy benefits such as fewer production disruptions, improved product quality, reduced waste and maintenance, and improved worker morale; these benefits have been previously acknowledged by researchers [35].

Previous research has emphasized the importance of considering individuals' underlying reasoning in order to create a shared understanding, commitment, and strategic consensus [51]. This is a bi-directional link: Although increasing awareness and creating legitimacy for strategic energy-efficiency goals can overcome the barrier of resistance for energy-efficiency improvements within organizations [70], the integration of non-energy benefits into economic reasoning for energy efficiency justifies strategic investments [35]. From this we arrive at the first proposition, stated below.

Proposition 1. Considering different actors' underlying reasoning for engaging in the process of energy-efficiency improvement can enable making energy efficiency strategic.

Although awareness due to regulations, market, and drivers does not necessarily translate into green practices, the findings confirm that external pressure (whose Swedish example includes the Programme for Improving Energy Efficiency in Energy-Intensive Industries (PFE)) contributes to prioritizing improving energy efficiency as a strategic issue through the involvement of the top management. It further contributes to triggering investments for implementing an energy management system (such as ISO50001), energy certification, and developing internal or external environmental reports that provide structure to the way of working and lead to a more standardized systematic approach. As noted by the interviewees:

"The PFE program was a big turning point for us in which we became aware of energy efficiency, perhaps in a different way. We went from being a little bit opportunistic and saying, 'Look, oh here, there is an opportunity,' to having an energy management system which actually looks after potentials, prioritize and implement them."

Moreover, considering energy-efficiency improvements as a prioritized strategic issue leads to investments in developing competences in different organizational layers. Competence development aligns the interests of the businesses with the interests and needs of individual employees, as found in Halldorsson et al.'s study [2]. This competence development enhances empowerment and develops vertical and horizontal involvement based on inputs and changes from employees with the full engagement and commitment of different actors. This brings forth the second proposition, stated below.

Proposition 2. Although the commitment of the top management and a structured, systematic, and standardized way of working (such as an energy management system) creates a momentum for the process of energy-efficiency improvements, competence development enhances empowerment and engagement among actors and creates a continuity to the process of energy-efficiency improvements.

Previous research has argued for the establishment of an energy manager with the possibility to integrate energy planning and initiate energy-saving activities corporate-wide as an internal factor for establishing a strategic perspective on energy management [13]. The importance of the role of an energy manager for enforcing values, creating awareness, and overcoming behavioral barriers has been acknowledged [21,65]. The need for a crossfunctional energy management team that reports directly to the management has also been 
previously discussed [17]. The analysis of the respondents' answers reveals the importance of creating a mandate for a dedicated responsible executive manager for energy-efficiency improvements close to operational decision-making. Respondents in companies in which ownership of improving energy efficiency is not clear or is far from the operational function pointed out that it is more likely that within the operational function, there is a champion who does not have a mandate for improving energy efficiency and is not involved in decision-making. In these companies, champions working to improve energy efficiency feel frustrated and do not understand how they can influence the process. For example, at the water-treatment company and in one of the companies in the aluminum industry, interviewees felt that they were alone in fighting for including improving energy efficiency as a part of the decisions made at the operational level.

A dedicated responsible executive manager close to the operational level can foster alignment of the top-down and bottom-up involvements by influencing decision-making using both energy and operational perspectives, transferring the strategic goals and decisions, and obtaining commitment through setting tactical goals and intertwining energy and operating decisions. Based on the statements provided by the interviewees, the executive managers usually have a broader perspective of operations than other employees in the organization and can identify the systems effects of the determinants of energy-efficiency improvements. Therefore, the existence of dedicated executive managers having responsibility for improving energy efficiency can ensure that goals for improving energy efficiency are not overcome by other operational priorities. This finding confirms prior OS research on the importance of coordination and communication between sustainability managers and operations executives to align the OS with the company's sustainability goals and establish the key role of operational executives in implementing these goals in day-to-day operational activities [23]. Moreover, a dedicated responsible executive manager close to the operational level can foster alignment of the inside-out and outside-in approaches by transferring the identified potential for energy-efficiency improvements from the operational function to the corporate level, securing funding, and working towards gathering the relevant measurement data to inform both the top management and external actors through internal and external reporting systems. This leads to the third proposition, stated below.

Proposition 3. Dedicated responsible executive managers for improving energy efficiency at the operational level facilitate the integrative approach in the process of energy-efficiency improvements.

The findings show that the closer the ownership for energy-efficiency improvements is to the operational function, the higher the likelihood is of these improvements being implemented and followed up on. For the studied companies that have moved the ownership of energy-efficiency improvements to the operational function (e.g., a metal powder company), the line organization has full responsibility for production and handles all issues-safety, quality, delivery, and environmental performance, including improving energy efficiency. By transferring ownership for improving energy efficiency to the operational function, energy efficiency is considered alongside the traditional operations performance objectives; this shift also leads to the consideration of the positive and negative impact of decisions for traditional operations performance objectives on improving energy efficiency. This can eventually lead to the bridging of energy and process issues for collaborative work as well as the consideration of all energy and non-energy benefits. Moreover, by moving the mandate for the operational function, the potential for energyefficiency improvements is enhanced by operational improvements through operational resources without a formal improvement project. According to the plant manager in the water-treatment company, the firm should move to measuring and paying for energy that each function actually consumes. He believed that this would create incentives for employees at each function, including operations, to understand that their own work affects energy-efficiency improvement. This leads to the final proposition, proposition 4 , which is stated below. 
Proposition 4. Transferring the ownership for the process of energy-efficiency improvements to the operational function affects the integration of energy-efficiency improvements in day-to-day operational practices and fosters the "how" to operationalize.

\section{Conclusions}

This study empirically investigates the involvement of actors in the process of energyefficiency improvements. By analyzing the results from studying actors' involvement in 19 companies, this paper identifies four different approaches, namely, top-down, bottom-up, outside-in, and inside-out, in the process of energy-efficiency improvements. Moreover, through a couple of propositions, the study enables incorporating energy-efficiency improvements in daily strategic and operational decisions and actions instead of regarding it as a separate or an add-on process. By conceptualizing and proposing a double-loop layered approach and highlighting the different kinds of knowledge and competences from actors involved, the paper offers an overview that can help actors involved in the process of improving energy efficiency in the organization to understand actors' underlying reasoning for engaging in the process of energy-efficiency improvement and thus align strategic goals for sustainable development, including energy-efficiency improvements, across and within different functions, including the operations function. Thus, the practical implication of the paper is related to understanding how to implement the double-loop layered approach in the process of energy-efficiency improvements to create a share understanding among all the actors and stimulate more engagement of them.

This paper has the following main theoretical contributions: First, the study provides an understanding of how firms can undertake the transition towards integrating strategic goals for energy efficiency into operations through actors' involvement. The study broadens the scope of sustainability in operations management by providing an understanding of energy-efficiency improvements as an emerging improvement process that allows for an emphasis on the development aspect of sustainable development as a "process of change" rather than a "fixed state of harmony" [25] (p. 43). By combining the four identified approaches into an integrative approach, not only can the energy-efficiency improvements be accomplished by linking the individual parts, but it can also ensure development over time through feedback layers that enable organizational learning for continuous improvement.

Second, although previous research on OM mainly focused on the impact of sustainability management on firms' performance and factors affecting or enhancing sustainability performance emanating from the institutional and organizational levels [44], this study goes beyond that in favor of sustainability as practice. Instead of focusing only on the top management's sustainability intent, this study focuses on different actors as a foundation for development efforts in the process of energy-efficiency improvements, which is in line with the call for more focus on the individual level [44] and behavioral and human factors to improve sustainable development [59].

Third, by applying a sustainability-as-practice approach among the actors involved, the study expands the scope of OS, following Adamides' [45] view, which suggests broadening the traditional top-down process. The study investigates different approaches and introduces new pathways for considering strategic goals for energy efficiency in operations by focusing actors' development efforts through in-depth interview studies. Moreover, it expands the operational focus on energy efficiency [17] and adds diverse perspective [13] by including various interviewees from different organizational levels.

The study has some limitations that call for further research. First, the propositions remain to be empirically tested, since the findings are limited to the nature of the interviews and are based on interviewees' perceptions. However, the respondents are the most knowledgeable in working with energy-efficiency improvement in their companies. Second, this study sought to respond to the call to look at both top-down and bottom-up approaches as well as different organizational structures, and hence, focusing on one organizational level would not have achieved the aim of the study. Accordingly, the respondents in this 
study were selected from different organizational levels, ranging from managing directors to operators. However, future research could adopt either a more focused approach on one organizational level or include data from different levels in all companies. Finally, the sustainable development of operations concerns all three dimensions of the sustainable development framework, namely, economic, environmental, and social. As such, this study, like many other studies on OM, has an environmental focus. Although the evidence suggests the importance of social interactions and involving individual employees, a comprehensive study considering all three dimensions simultaneously should also be considered.

Funding: This research received no external funding.

Institutional Review Board Statement: Not applicable.

Informed Consent Statement: Not applicable.

Conflicts of Interest: The authors declare no conflict of interest.

\section{References}

1. Naranjo-Gil, D. The role of management controls systems and top management teams in implementing environmental sustainability policies. Sustainability 2016, 8, 359. [CrossRef]

2. Halldorsson, A.; Gremyr, I.; Winter, A.; Taghahvi, N. Lean energy: Turning sustainable development into organizational renewal. Sustainability 2018, 10, 4464. [CrossRef]

3. Rasmussen, J. The Role of Structural Context in Making Business Sense of Investments for Sustainability-A Case Study. Sustainability 2020, 12, 7006. [CrossRef]

4. Fleiter, T.; Hirzel, S.; Worrell, E. The characteristics of energy-efficiency measures-A neglected dimension. Energy Policy 2012, 51, 502-513. [CrossRef]

5. Yacob, P.; Wong, L.S.; Khor, K.C. An empirical investigation of green initiatives and environmental sustainability for manufacturing SMEs. J. Manuf. Technol. Manag. 2019, 30, 2-25. [CrossRef]

6. Koh, S.; Morris, J.; Ebrahimi, S.M.; Obayi, R. Integrated resource efficiency: Measurement and management. Int. J. Oper. Prod. Manag. 2016, 36, 1576-1600. [CrossRef]

7. Schulze, M.; Nehler, H.; Ottonsson, M.; Thollander, P. Energy management in industry-A systematic review of previous findings and an integrative conceptual framework. J. Clean. Prod. 2016, 112, 3692-3708. [CrossRef]

8. Sola, A.V.; Mota, C.M. Influencing factors on energy management in industries. J. Clean. Prod. 2020, 248, 119263. [CrossRef]

9. Kluczek, A. An energy-led sustainability assessment of production systems-An approach for improving energy efficiency performance. Int. J. Prod. Econ. 2019, 216, 190-203. [CrossRef]

10. Abdelaziz, E.A.; Saidur, R.; Mekhilef, S. A review on energy saving strategies in industrial sector. Renew. Sustain. Energy Rev. 2011, 15, 150-168. [CrossRef]

11. Brunke, J.C.; Johansson, M.; Thollander, P. Empirical investigation of barriers and drivers to the adoption of energy conservation measures, energy management practices and energy services in the Swedish iron and steel industry. J. Clean. Prod. 2014, 84, 509-525. [CrossRef]

12. May, G.; Stahl, B.; Taisch, M.; Kiritsis, D. Energy management in manufacturing: From literature review to a conceptual framework. J. Clean. Prod. 2017, 167, 1464-1489. [CrossRef]

13. Rudberg, M.; Waldermarsson, M.; Lidestam, H. Strategic perspectives on energy management: A case study in the process industry. Appl. Energy 2013, 104, 487-496. [CrossRef]

14. Papke-Shilds, K.E.; Malhotra, M.K. Assessing the impact of the manufacturing executive's role on business performance through strategic alignment. J. Oper. Manag. 2001, 19, 5-22. [CrossRef]

15. Longoni, A.; Cagliano, R. Cross-functional executive involvement and worker involvement in lean manufacturing and sustainability alignment. Int. J. Oper. Prod. Manag. 2015, 35, 1332-1358. [CrossRef]

16. González-Sánchez, D.; Suárez-González, I.; Gonzalez-Benito, J. Human resources and manufacturing: Where and when should they be aligned? Int. J. Oper. Prod. Manag. 2018, 38, 1498-1518. [CrossRef]

17. Martin, R.; Muûls, M.; de Preux, L.B.; Wagner, U.J. Anatomy of a paradox: Management practices, organizational structure and energy efficiency. J. Environ. Econ. Manag. 2012, 63, 208-223. [CrossRef]

18. Hasanbeigi, A.; Price, L.; Chunxia, Z.; Aden, N.; Xiuping, L.; Fangqin, S. Comparison of iron and steel production energy use and energy intensity in China and the U.S. J. Clean. Prod. 2014, 65, 108-119. [CrossRef]

19. Blass, V.; Corbett, C.J.; Delmas, M.A.; Muthulingam, S. Top management and the adoption of energy efficiency practices: Evidence from small and medium-sized manufacturing firms in the US. Energy 2014, 65, 560-571. [CrossRef]

20. Apeaning, R.W.; Thollander, P. Barriers to and driving forces for industrial energy efficiency improvements in African industriesA case study of Ghana's largest industrial area. J. Clean. Prod. 2013, 53, 204-213. [CrossRef] 
21. Trianni, A.; Cagno, E.; Farne, S. Barriers, drivers and decision-making process for industrial energy efficiency: A broad study among manufacturing small and medium-sized enterprises. Appl. Energy 2016, 162, 1537-1551. [CrossRef]

22. Chiaroni, D.; Chiesa, M.; Chiesa, V.; Franzo, S.; Frattini, F.; Toletti, G. Introducing a new perspective for the economic evaluation of industrial energy efficiency technologies: An empirical analysis in Italy. Sustain. Energy Technol. Assess. 2016, 15, 1-10. [CrossRef]

23. Longoni, A.; Pagell, M.; Shevchenko, A.; Klassen, R. Human capital routines and sustainability trade-offs: The influence of conflicting schemas for operations and safety managers. Int. J. Oper. Prod. Manag. 2019, 39, 690-713. [CrossRef]

24. Anand, G.; Ward, P.T.; Tatikonda, M.V.; Schilling, D.A. Dynamic capabilities through continuous improvement infrastructure. J. Oper. Manag. 2009, 27, 444-461. [CrossRef]

25. World Commission on Environment and Development. Our Common Future; Oxford University Press: Oxford, UK, 1987.

26. Longoni, A.; Cagliano, R. Environmental and social sustainability priorities: Their integration in operations strategies. Int. J. Oper. Prod. Manag. 2015, 35, 216-245. [CrossRef]

27. Ferdows, K.; De Meyer, A. Lasting improvements in manufacturing performance: In search of a new theory. J. Oper. Manag. 1990, 9, 168-184. [CrossRef]

28. Hayes, R.H.; Wheelwright, S.C. Restoring Our Competitive Edge: Competing through Manufacturing; John Wiley \& Sons: Hoboken, NJ, USA, 1984.

29. Jabbour, C.J.C.; Da Silva, E.M.; Paiva, E.L.; Santos, F.C.A. Environmental management in Brazil: Is it a completely competitive priority? J. Clean. Prod. 2012, 21, 11-22. [CrossRef]

30. Besiou, M.; Van Wassenhove, L. Addressing the challenge of modeling for decision-making in socially responsible operations. Prod. Oper. Manag. 2015, 24, 1390-1401. [CrossRef]

31. Pagell, M.; Gobeli, D. How plant managers' experiences and attitudes toward sustainability relate to operational performance. Prod. Oper. Manag. 2009, 18, 278-299. [CrossRef]

32. Gimenez, C.; Sierra, V.; Rodon, J. Sustainable operations: Their impact on the triple bottom line. Int. J. Prod. Econ. 2012, 140, 149-159. [CrossRef]

33. Graham, S.; MacAdam, R. The effects of pollution prevention on performance. Int. J. Oper. Prod. Manag. 2016, 36, 1333-1358. [CrossRef]

34. Abdul-Rashid, S.H.; Evans, S.; Longhurst, P.A. A comparison of four sustainable manufacturing strategies. Int. J. Sustain. Eng. 2008, 1, 214-229. [CrossRef]

35. Nehler, T. A systematic literature review of methods for improved utilisation of the non-energy benefits of industrial energy efficiency. Energies 2018, 11, 3241. [CrossRef]

36. Virtanen, T.; Tuomaala, M.; Pentti, E. Energy efficiency complexities: A technical and managerial investigation. Manag. Account. Res. 2013, 24, 401-416. [CrossRef]

37. Bui, B.; de Villiers, C. Carbon emissions management control systems: Field study evidence. J. Clean. Prod. 2017, 166, 1283-1294. [CrossRef]

38. Bunse, K.; Vodicka, M.; Schönsleben, P.; Brülhart, M.; Ernst, P.O. Integrating energy efficiency performance in production management-Gap analysis between industrial needs and scientific literature. J. Clean. Prod. 2011, 19, 667-679. [CrossRef]

39. Solnørdal, M.; Foss, L. Closing the Energy Efficiency Gap-A Systematic Review of Empirical Articles on Drivers to Energy Efficiency in Manufacturing Firms. Energies 2018, 11, 518. [CrossRef]

40. Directive 2012/27/EU on Energy Efficiency. The European Parliament and the Council of the European Union Amending Directives 2009/125/EC and 2010/30/EU and Repealing Directives 2004/8/EC and 2006/32/EC. Available online: https: / / eur-lex.europa.eu/LexUriServ/LexUriServ.do?uri=OJ:L:2012:315:0001:0056:en:PDF (accessed on 15 April 2021).

41. Thollander, P.; Ottosson, M. Energy management practices in Swedish energy-intensive industries. J. Clean. Prod. 2010, 18, 1125-1133. [CrossRef]

42. Benedetti, M.; Cesarotti, V.; Introna, V. From energy targets setting to energy-aware operations control and back: An advanced methodology for energy efficient manufacturing. J. Clean. Prod. 2017, 167, 1518-1533. [CrossRef]

43. Epstein, M.J. Making Sustainability Work; Greenleaf Publishing: Sheffield, UK, 2008.

44. Wesselink, R.; Blok, V.; van Leur, S.; Lans, T.; Dentoni, D. Individual competencies for managers engaged in corporate sustainable management practices. J. Clean. Prod. 2015, 106, 497-506. [CrossRef]

45. Adamides, E.D. Linking operations strategy to the corporate strategy process: A practice perspective. Bus. Process Manag. J. 2015, 21, 267-287. [CrossRef]

46. Kim, Y.H.; Sting, F.J.; Loch, C.H. Top-down, bottom-up, or both? Toward an integrative perspective on operations strategy formation. J. Oper. Manag. 2014, 32, 462-474. [CrossRef]

47. Azapagic, A. Systems approach to corporate sustainability: A general management framework. Process Saf. Environ. Prot. 2003, 81, 303-316. [CrossRef]

48. Pagell, M.; Wu, Z. Building a more complete theory of sustainable supply chain management using case studies of 10 exemplars. J. Supply Chain Manag. 2009, 45, 37-56. [CrossRef]

49. Bansal, P.; Roth, K. Why companies go green: A model of ecological responsiveness. Acad. Manag. J. 2000, 43, 717-736. [CrossRef]

50. Kiridena, S.; Hasan, M.; Kerr, R. Exploring deeper structures in manufacturing strategy formation processes: A qualitative inquiry. Int. J. Oper. Prod. Manag. 2009, 29, 386-417. [CrossRef] 
51. Edh Mirzaei, N.; Fredriksson, A.; Winroth, M. Strategic consensus on manufacturing strategy content: Including the operators' perceptions. Int. J. Oper. Prod. Manag. 2016, 36, 429-466. [CrossRef]

52. Daily, B.F.; Huang, S. Achieving sustainability through attention to human resource factors in environmental management. Int. J. Oper. Prod. Manag. 2001, 21, 1539-1552. [CrossRef]

53. Burritt, R.L.; Schaltegger, S. Sustainability accounting and reporting: Fad or trend? Account. Audit. Account. J. 2010, 23, 829-846. [CrossRef]

54. Saeed, S.; Yousafzai, S.; Paladino, A.; De Luca, L.M. Inside-out and outside-in orientations: A meta-analysis of orientation's effects on innovation and firm performance. Ind. Mark. Manag. 2015, 47, 121-133. [CrossRef]

55. Maas, K.; Schaltegger, S.; Crutzen, N. Integrating corporate sustainability assessment, management accounting, control, and reporting. J. Clean. Prod. 2016, 136, 237-248. [CrossRef]

56. Barney, J.B. Firm resources and sustained competitive advantage. J. Manag. 1991, 17, 99-120. [CrossRef]

57. Hancock, G. How GE's Treasure Hunts Discovered More than 110M in Energy Savings. Available online: https://www.greenbiz. $\mathrm{com} / \mathrm{blog} / 2009 / 05 / 13 /$ how-ges-treasure-hunts-discovered-more-110m-energy-savings (accessed on 21 January 2017).

58. Elliott, R. Vendors as Industrial Energy Service Providers. American Council for an Energy-Efficient Economy (ACEEE) White Paper. 2002. Available online: http:/ /aceee.org/industry/vendors.pdf (accessed on 24 September 2019).

59. Walker, P.H.; Seuring, P.; Sarkis, P.; Klassen, P. Sustainable operations management: Recent trends and future directions. Int. J. Oper. Prod. Manag. 2014, 34. [CrossRef]

60. Flick, U. An Introduction to Qualitative Research; Sage Publications Limited: Thousand Oaks, CA, USA, 2018.

61. Bryman, A.; Bell, E. Business Research Methods; Oxford University Press: Oxford, UK, 2015.

62. Rohdin, P.; Thollander, P.; Solding, P. Barriers to and drivers for energy efficiency in the Swedish foundry industry. Energy Policy 2007, 35, 672-677. [CrossRef]

63. Yin, R.K. Case Study Research: Design and Methods; Sage Publications: Thousand Oaks, CA, USA, 2009.

64. Corbin, J.; Strauss, A. Basics of Qualitative Research: Techniques and Procedures for Developing Grounded Theory; Sage Publications: Thousand Oaks, CA, USA, 2007.

65. Cooremans, C.; Schönenberger, A. Energy management: A key driver of energy-efficiency investment? J. Clean. Prod. 2019, 230, 264-275. [CrossRef]

66. Wu, Z.; Pagell, M. Balancing priorities: Decision-making in sustainable supply chain management. J. Oper. Manag. 2011, 29, 577-590. [CrossRef]

67. Zhu, Q.; Sarkis, J.; Geng, Y. Green supply chain management in China: Pressures, practices and performance. Int. J. Oper. Prod. Manag. 2005, 25, 449-468. [CrossRef]

68. Zailani, S.; Eltayeb, T.; Hsu, C.; Tan, K. The impact of external institutional drivers and internal strategy on environmental performance. Int. J. Oper. Prod. Manag. 2012, 32, 721-745. [CrossRef]

69. Alblas, A.; Peters, K.; Wortmann, H. Fuzzy sustainability incentives in new product development: An empirical exploration of sustainability challenges in manufacturing companies. Int. J. Oper. Prod. Manag. 2016, 34, 513-545. [CrossRef]

70. Battaglia, M.; Passetti, E.; Bianchi, L.; Frey, M. Managing for integration: A longitudinal analysis of management control for sustainability. J. Clean. Prod. 2016, 136, 213-225. [CrossRef] 